\title{
Physiologically-active compounds in plant foods: an overview
}

\author{
BY M. J. C. RHODES \\ Bioactive Compounds Group, Department of Food Molecular Biochemistry, Institute of Food \\ Research, Norwich Research Park, Colney, Norwich NR4 7UA
}

\section{Composés physiologiquement actifs dans les aliments d'origine végétale: aperçu général}

\begin{abstract}
RÉSUMÉ
Les plantes contiennent une gamme étendue de métabolites secondaires de faible poids moléculaire qui sont importants pour protéger la plante contre les attaques de prédateurs et de pathogènes, dans l'interaction de la plante avec son environnement, et comme facteurs dans la pollénisation et la dispersion des graines. Les aliments d'origine végétale consommés par l'homme contiennent de nombreux composés qui peuvent avoir soit des effets indésirables dans l'alimentation en tant qu'éléments naturels toxiques, soit des effets bénéfiques en tant qu'anti-oxydants et qu'éléments protecteurs contre les maladies dégénératives telles que le cancer et les maladies coronariennes. La preuve épidémiologique, qui suggère que les régimes riches en fruits et légumes sont corrélés avec une faible incidence de toute une gamme de cancers, a orienté cette discussion sur les effets protecteurs possibles des métabolites secondaires des plantes dans l'alimentation. Cet article se concentre sur trois classes de composés dérivés des plantes qui ont été impliqués comme ayant des effets alimentaires bénéfiques, les flavonoïdes, et les produits de dégradation des glucosinolates dans les brassicas et des alliacés (dérivés sulfoxydés de la cystéine) dans les oignons et l'ail. Nous nous concentrerons sur la forme de ces composés dans les aliments d'origine végétale et sur les processus qui affectent leur biodisponibilité.

L'importance de la prise des flavonoïdes par l'alimentation reste quelque peu controversée. Kühnau (1973) estimait la prise des flavonoïdes (en tant que glycosides) dans l'alimentation aux USA à environ $1000 \mathrm{mg} /$ jour, dont environ $16 \%$ en provenance de 4-oxo-flavonoïdes (flavones, flavanols, etc. . . .), 17\% d'anthocyanines, $20 \%$ de catéchines et $45 \%$ de tanins. Hertog et al. (1993b) ont fait des estimés détaillés des prises de 4-oxo-flavonoïdes aux Pays-Bas, fondés sur des procédures analytiques modernes de flavonoïdes, et calculé une prise quotidienne (exprimée en glycosides) d'environ 23 $\mathrm{mg} /$ jour. Ce résultat est environ cinq fois moindre que l'estimé de Kühnau (1973) lorsqu'on l'exprime sur la même base. Il est possible que les chiffres précédents plus élevés reflètent des déficiences dans les données analytiques sur lesquelles ils étaient fondés, et que les mêmes critiques s'appliquent aux données sur les anthocyanines, les catéchines et les tanins. Il semble vraisemblable que les valeurs de Kühnau (1973) sont surestimées, mais les prises totales sont considérablement plus élevées que la valeur de $23 \mathrm{mg} / \mathrm{jour}$ donnée par Hertog et al. (1993b) lorsque toutes les classes de flavonoïdes sont prises en compte. Cependant, la forme des flavonoïdes dans la nourriture consommée n'est pas encore clairement définie; le degré de captation et le métabolisme des flavonoïdes dans les cellules intestinales et dans le flux sanguin n'est pas connu.
\end{abstract}


Les brassicas contiennent une gamme de composés contenant du soufre, les glucosinolates. Ils sont décomposés à la suite de différents dommages, dont la mastication, et par l'enzyme de la plante, la myrosinase ( $E C$ 3.2.3.1), pour produire une gamme de produits contenant du soufre et physiologiquement actifs. Ils comprennent des isothiocyanates, qui se sont révélés être d'actifs anticarcinogènes dans des modèles expérimentaux animaux. L'activité de la myrosinase est stimulée par l'ascorbate qui est un effecteur de cette enzyme. La nature des produits formés est influencée par le pH de la cellule et par la nature du substrat de glucosinolate endogène. Normalement les brassicas sont cuits, et il est possible que le degré de dégradation thermique des glucosinolates génère des composés actifs. De plus, dans l'intestin il y a des bactéries qui contiennent des thioglucohydrolases, semblables aux myrosinases des plantes, qui pourraient attaquer les glucosinolates pour générer des molécules bioactives pendant la digestion. L'importance relative de ces différentes voies de la dégradation du glucosinolate dans la formation de composés alimentaires actifs reste à être étudiée.

Les alliacés (oignons, ail, ciboulette, poireau) contiennent une gamme de composés du soufre qui sont des dérivés du sulphoxyde de L-cystéine (SOC) qui sont localisés dans le cytoplasme des cellules d'oignon, et maintenus séparés de l'enzyme hydrolytique, l'alliinase ( $E C$ 4.4.1.4) présente dans la vacuole de la cellule. A l'éclatement de la cellule, les dérivés de SOC sont décomposés pour produire une gamme de produits contenant du soufre tels que les mono-, di- et tri-sulphates dialk(en)yl, les thiols et une grande quantité de composés du soufre tels que l'ajoene, et des composés non sulfureux comprenant des aldéhydes, dont certains ont été impliqués comme facteurs protecteurs potentiels dans l'alimentation contre la maladie dégénérative. La biodisponibilité des glucosinolates et des produits de CSO est difficile à expliquer étant donné la diversité des produits formés à la suite de leur dégradation enzymatique et de par l'implication possible des voies de dégradation thermale et microbienne. Ces problèmes de biodisponibilité doivent être résolus avant que la contribution de ces facteurs protecteurs potentiels contre les maladies dégénératives chez l'homme puisse être évaluée avec exactitude.

Plants contain a wide range of low-molecular-weight secondary metabolites which are important in protecting the plant against attack by predators and pathogens, in the interaction of the plant with its environment and as factors in flower pollination and seed dispersal. Plants lack a system equivalent to the immune system of animals based on peptide chemistry and instead rely on a diversity of low-molecular-weight chemicals which function in conjunction with physical barriers and some defensive enzymes to provide a system of defence against physiological stress and attack by other organisms (Rhodes, 1994). Many wild plants are toxic to phytophagous animals and across the plant kingdom a vast diversity of plant secondary metabolites has been described by natural-product chemists. Amongst these compounds are representatives of many different chemical classes (alkaloids, phenolics, terpenoids etc.), great variety in the derivatives within each class and often high degrees of stereochemical selectivity among the compounds actually accumulating.

Among the few hundred plant species that humans regularly eat as food, there has been considerable selection for plants and varieties low in toxicants. Selection has also tended to promote the retention of those secondary metabolites which provide positive 
organoleptic or visual characteristics such as flavour compounds and pigments and the reduction of those with adverse acceptability properties such as the tannins. Thus, current food plant varieties tend to have somewhat reduced endogenous defences against pathogens and predators and have to be defended by exogenously-supplied pesticides and agrochemicals. Nevertheless, food plants retain significant levels of secondary metabolites, which in the broadest sense are biologically-active molecules that have evolved in the interaction between the plant and other organisms. With any diet in which plant foods form a significant element, a diverse range of plant secondary metabolites is ingested; some are potentially toxic to humans, as metabolic inhibitors or enzyme inactivators. They may enter human gut or liver cells and be metabolized, and they or their metabolic products may have either positive or negative effects on the biochemistry of the human cells.

In the past, there has been emphasis put on secondary metabolites as natural toxicants present in plant foods such as glycoalkaloids in potatoes and tomatoes, cyanogenic glycosides in cassava etc., and their potential for damage in man. However, the epidemiological evidence which suggests that diets rich in fruit and vegetables are correlated with low incidence in a whole range of cancers (Block et al. 1992) has refocused this discussion. The extent to which the beneficial effects of high intakes of fruit and vegetables can be ascribed to their content of plant secondary metabolites as opposed to higher intakes of vitamin antioxidants is a matter of current research (Johnson et al. 1994).

The present paper will concentrate on three classes of plant-derived compounds which have been implicated as having beneficial dietary effects. These compounds fall into two distinct classes. In the first are the flavonoids which are endogenous plant compounds with particular properties that fit them for a protective role. The second group comprises the glucosinolates in Brassicas and the alliins in onions (Allium cepa) and garlic (Allium sativum) in which the putative protective compounds are not themselves plant constituents but are derived from them (such as isothiocyanates and diallyl sulphides), at least in part, by the action of endogenous plant hydrolytic enzymes. In both Brassica and Allium plants, the degradative enzyme is held apart from its substrate in intact tissue and can only act after a degree of cellular damage has occurred allowing autolytic reactions to proceed.

\section{FLAVONOIDS AS ENDOGENOUS PROTECTIVE FACTORS}

The flavonoids are a related group of compounds based on the flavone nucleus, biosynthetically derived from phenylalanine and malonate. The various classes of flavonoids differ in the level of oxidation and pattern of substitution of the $\mathrm{C}$ ring (Fig. 1). Individual compounds within a class differ in the pattern of substitution of the $A$ and $\mathrm{B}$ rings. From a dietary point of view, the most important classes of flavonoids are the flavones and flavonols, the catechins and related tannins based on the flavan-3-ol structure and the anthocyanins, the pigments responsible for the red and blue colours of many fruits and vegetables. Related to these compounds are the isoflavones which have activity as phyto-oestrogens in which the aromatic $B$ ring is attached to position 3 of the $\mathrm{C}$ ring rather than position 2 as in the flavonoid series. Whereas the flavonoids are found in nearly all fruit and vegetables, the isoflavones are largely limited to one plant family, the Leguminosae (pea family). 


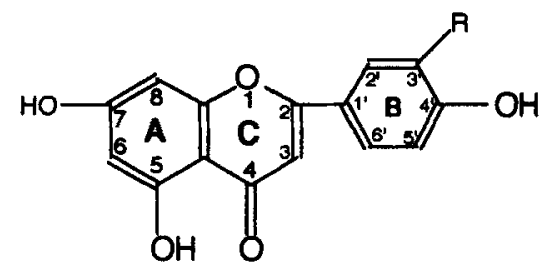

$$
\begin{aligned}
& R=H \quad \text { Apigenin } \\
& R=O H \text { Luteolin }
\end{aligned}
$$

Flavonals<smiles>[R]c1cc(-c2oc3cc(O)cc(O)c3c(=O)c2O)ccc1O</smiles>

Flavan-3-ols<smiles>[R]c1cc([C@@H]2Oc3cc(O)c4c(O)c3CC(O)[C@@H]4O2)ccc1O</smiles><smiles></smiles>

\section{$\mathbf{R}=\mathrm{H}$ Pelargonidin.}

$\mathrm{R}=\mathrm{OH}$ Cyanidin

Fig. 1. Some major classes of flavone aglycones found in plant foods.

Many of the data for the flavonoid content of plant foods in the literature are based on hydrolysed samples and the analysis of aglycones. However, with the exception of some of the flavan-3-ols, flavonoids are almost exclusively present as conjugates. In intact tissue, the aglycones only exist at low levels as metabolic intermediates. Low levels of aglycones are detected in tissue which has been damaged or has undergone senescence where a degree of autolysis has occurred. Flavonoids accumulate in plants largely as glycosides. In the flavonol and anthocyanin series, conjugation through the 3 position of the $\mathrm{C}$ ring is common but also frequently occurs through 5 and 7 positions on the $\mathrm{A}$ ring. Glycosylation of the B-ring hydroxyls occurs less commonly but is found in some vegetables including the onion. A wide range of sugars are involved: glucose, galactose 
and rhamnose, also sugar oligomers such as sophorose (2-O- $\beta$-D-glucosyl-D-glucose) and rutinose (6-O-glucose- $\alpha$-L-rhamnosyl-D-glucose) and occasionally unusual sugars such as apiose and allose. In addition, acylation of the sugar hydroxyl groups with organic acids such as malonate and acetate commonly occurs, but acylation with phenolic acids such as $p$-coumaric, caffeic and ferulic acids also occurs particularly with anthocyanins. The pattern of conjugation can be very complex and can significantly modify the hydrophilicity of the molecule and its biological properties and also markedly increases the molecular weight of the flavonoid.

The level of intake of flavonoids from the diet is a matter of some controversy. There are difficulties in estimating intakes, as pointed out by Pierpoint (1990). Flavonoids exist in many different classes and their content in plants is influenced very significantly by season maturity, variety and environmental stress. They commonly exist in plants as conjugates with sugars and organic acids. Kühnau (1973) estimated the intake of flavonoids (as glycosides) in the US diet as about $1000 \mathrm{mg} / \mathrm{d}$, of which $16 \%$ was from 4-oxoflavonoids (flavones, flavanols etc.), 17\% from anthocyanins, $20 \%$ from catechins and $45 \%$ from tannins. Pierpoint (1990) pointed out that the average UK consumption of tea would provide of itself $900 \mathrm{mg} / \mathrm{d}$, almost equivalent to the entire US intake, and that individual daily intakes of 2-3 g/d are not unlikely. Hertog et al. (1993b) have made detailed estimates of intakes of 4-oxoflavonoids based on modern analytical procedures of flavonoids in the Dutch diet. They concluded that tea, onions, and apples were the major sources and calculated a daily intake (expressed as aglycones) of about $23 \mathrm{mg} / \mathrm{d}$. This is about 5-fold lower than the estimate of Kühnau (1973) when expressed on the same basis. The higher earlier values may reflect deficiencies in the analytical data on which they were based and similar criticisms may extend to the data on anthocyanins, catechins and tannins. It seems likely that the Kühnau (1973) value is an overestimate, but actual intakes are considerably greater than the value of $23 \mathrm{mg} / \mathrm{d}$ given by Hertog et al. $(1993 \mathrm{~b})$ when all flavonoid classes are taken into account. One factor affecting these levels of intake of flavonoids between populations is clearly variations in the intake of beverages such as tea and wine. High levels of flavonols, catechins and tannins are present in both tea and wine and variations in intake of these beverages may have an important bearing on overall flavonoid amounts consumed in different national diets.

Among individual 4-oxo-flavonoids, quercetin and kaempferol conjugates are the major constituents in the diet; for example, onions, a major flavonoid source, contain up to $1.2-1.6 \mathrm{mg}$ quercetin glycosides/g fresh weight. As befits compounds involved in the defence of plants, flavonoids are often concentrated on the surface of plant organs, such as the red pigments and other flavonoids in radishes (Raphanus sativus) and grapes.

Kühnau (1973) has proposed flavonoids as semi-essential food components. Table 1 lists some potentially beneficial properties of flavonoids in the diet. Some flavonoids show strong antioxidant activity. Strong phenolic antioxidants such as quercetin and the anthocyanin aglycone, cyanidin, have antioxidant potentials 4-fold higher than that of the vitamin $\mathrm{E}$ analogue, trolux (Rice-Evans et al. 1995). The major structural requirements for antioxidant activity are the presence of ortho-dihydroxyl groups on the B ring, the presence of a 2,3-double bond in the $\mathrm{C}$ ring and free hydroxyl groups on the 5 and 7 position of the A ring (Rice-Evans et al. 1995). Quercetin, which meets these requirements, is a potent inhibitor of lipid peroxidation (Das \& Ratty, 1986). Flavonoids (Leibovitz \& Mueller, 1993) are good chelators of metals such as $\mathrm{Cu}$ and $\mathrm{Fe}$, they inhibit platelet aggregation and have anti-viral and anti-bacterial properties. They protect 
Table 1. Some properties of flavonoids relevant to their dietary effects

\begin{tabular}{ll}
\hline & Antioxidant properties \\
Metal chelation \\
Anti-viral activity \\
Anti-bacterial activity \\
Anti-inflammatory properties \\
Oestrogenic activity \\
Mutagenic properties \\
Anti-mutagenic activity \\
Enzyme activators and/or inhibitors \\
\hline
\end{tabular}

against the mutagenicity of compounds, such as the indolic carcinogen (Trp-P-2), which are formed during cooking of meat (Sanejima et al. 1995). Flavonoids are potential inhibitors of cellular enzymes, yet are inducers of anti-cancer enzymes. This is illustrated from our own work which shows that flavonoids such as quercetin can induce the phase-II anti-carcinogenic enzyme, glutathione S-transferase (EC 2.5.1.18; GST) in human cells in culture (M. J. C. Rhodes, G. W. Williams, J. Bacon and S. DuPont, unpublished results).

Experiments in animal model systems have shown that flavonoids can reverse chemically-induced carcinogenesis (for review, see Leibovitz \& Mueller, 1993), but whether similar mechanisms operate in humans remains unresolved. In other degenerative diseases there is correlative evidence of a protective effect. Studies on an elderly population in the Netherlands show significant differences in the incidence of coronary heart disease between populations with upper and lowest tertiles of flavonoid intake; high intake being correlated to a low incidence of heart disease (Hertog et al. 1993a). In spite of the fact that individual flavonoids at relatively high concentrations can be shown to be potential mutagens in in vitro tests, the overall nutritional effect of dietary levels of flavonoids is likely to be beneficial.

However, many problems persist in our understanding of the extent of the bioavailability of dietary flavonoids. The form of flavonoids in food as eaten is still not clearly defined, the degree of uptake and metabolism of flavonoids into gut cells and into the bloodstream is unresolved (for review, see Hackett, 1986). It is difficult to gauge the level of exposure of gut and liver cells to flavonoids and to relate evidence obtained in in vitro experiments to the in vivo situation in humans. However, studies in which rats were fed the flavone aglycone, diosmetin, at relatively high levels equivalent to 100 $\mathrm{mg} / \mathrm{kg}$ body weight showed that diosmetin could not be detected in blood samples. However, the glucuronide derivative of diosmetin was found in blood samples at up to 10 $\mu \mathrm{g} / \mathrm{ml}$ within $6 \mathrm{~h}$ after treatment (Boutin et al. 1993). This indicates that flavonoid uptake and metabolism, possibly involving a UDP-glucuronate transferase, is active in rats. Similar information is not available for humans. The chemically-closely-related compounds, the isoflavones, however, appear to be readily taken up into the bloodstream in humans (Aldercreutz et al. 1993) to produce recognizable metabolic products and to elicit a physiological response by delaying menstruation (Cassidy et al. 1994).

Another factor which needs to be taken into account in assessing the bioavailability of flavonoids is the possibility of their binding to proteins. With one group of flavonoids, the tannins, it is well established that they form complexes with salivary proteins and that their passage through the gut is as tannin-protein complexes (Murray \& Williamson, 
1994). It is argued that this protects against some of the anti-nutritional properties of tannins. The proteins involved are salivary proteins with a high proline content (Azen et al. 1993). These proline-rich proteins bind large and moderately-sized tannins very tightly with affinities of the same order as in antibody-antigen interactions (Hagerman \& Butler, 1981). These proteins bind simple flavonoids much less firmly than the tannins. The problem of the bioavailability of flavonoids is an active area of current research and we can look forward to the resolution of these problems and a proper assessment of the importance of flavonoids in the diet.

\section{SULPHUR COMPOUNDS FROM BRASSICA AND ALLIUM VEGETABLES AS PROTECTIVE FACTORS IN THE DIET}

Although flavonoids are widely distributed and found in all plant food, the two groups of compounds to be discussed here are of only limited distribution but their importance is that they are present in widely eaten plant foods. The glucosinolates occur principally in the genus Brassica of the Cruciferae (the cabbage family), while the alliins (alk(en)yl cysteine sulphoxides) are found in the onion family in the genus Allium. These groups differ from the flavonoids in that the putative protective factors are compounds derived from the endogenous compounds not the endogenous compounds themselves.

\section{Glucosinolate breakdown products in brassicas}

Glucosinolates are a group of S-containing compounds of the structure:

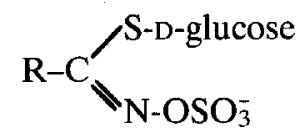

of which over 100 have so far been described. The individual compounds differ in the nature of the $R$ substituent, with the main classes of glucosinolates (Table 2) being alkenyl derivatives such as sinigrin, gluconapin and progoitrin, sulphinyl derivatives such as glucoiberin, aromatic derivatives such as gluconasturtin and glucosinalbin, and indolyl derivatives such as glucobrassicin. Table 2 shows the distribution of different classes of glucosinolates between various Brassica vegetables. Brussels sprouts (Brassica oleracea gemmifera) have the highest content of glucosinolates at up to $200 \mathrm{mg} / 100 \mathrm{~g}$ fresh weight, of which sinigrin, glucoiberin, progoitrin and glucobrassicin are major components. Purple broccoli (Brassica oleracea var italica Plenk) and savoy cabbage (Brassica oleracea var sabaïda L.) contain mainly glucoiberin and glucobrassicin, while turnips (Brassica rapa spp. rapa L.) are rich in gluconapin, gluconasturtin and progoitrin.

Glucosinolates in cells of the Brassica vegetables are held apart from the hydrolytic enzyme, myrosinase ( $E C$ 3.2.3.1). Thus, the putative protective factors formed in Brassica vegetables, the isothiocyanates, are not present in intact, undamaged tissue and are formed only when tissue damage occurs which allows the myrosinase to leach from the vacuoles of specialized cells (myrosin cells) in which it is housed in intact tissue and to attack and degrade the glucosinolates. This enzyme catalyses a very rapid reaction involving the cleavage of glucosinolates to form D-glucose and an unstable intermediate, a thiohydroximate-O-sulphonate, which depending on the conditions undergoes chemical degradaton to yield a range of S-containing products including isothiocyanates, thiocyanates and nitriles. 


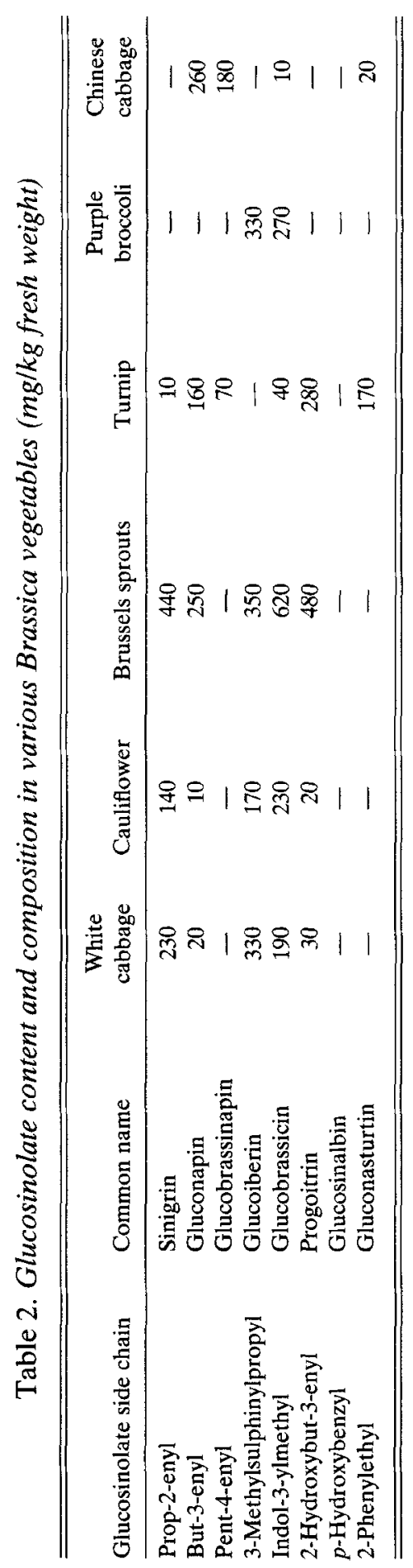


Myrosinase is a well-characterized glycoprotein which has been cloned from a number of plant sources (Xue et al. 1992). The nature of the products formed depends on the nature of the glucosinolate substrate, $\mathrm{pH}$ and the presence of other activators and inhibitors. Myrosinase is enzymically active over a wide range of $\mathrm{pH}$; at neutral $\mathrm{pH}$ the main products of its action are isothiocyanates, while at acid $\mathrm{pH}$ nitrile formation predominates. In the case of the indolylglucosinolates at neutral $\mathrm{pH}$ the initially formed indolyl isothiocyanate further degrades with loss of $S$ to form indole-3-carbinol and related compounds which are anti-carcinogens (Wattenberg \& Loub, 1978) and may play a protective role in the diet. Another factor which is important in relation to myrosinase activity is the concentration of ascorbate. Ascorbate is not a reactant in myrosinasecatalysed reactions but acts as an activator of the enzyme. This is illustrated by the work of Wilkinson et al. (1984) in which it was shown that ascorbate at 2-3 mм induced a 10 -fold activation of myrosinases from a range of cruciferous vegetables.

Enzymic breakdown of glucosinolates is clearly an important source of compounds such as indole-3-carbinol and the various isothiocyanates which may have beneficial dietary roles. However, Brassica vegetables are normally cooked and the thermal degradation of glucosinolates is a factor. Further, in the gut there are bacteria which contain thioglucohydrolases similar to the plant myrosinases and, thus, active breakdown products may be generated during digestion. The relative importance of these different routes of glucosinolate degradation in the generation of active dietary compounds has yet to be resolved.

Among the Brassica glucosinolate breakdown products which have been implicated as having dietary benefit are the isothiocyanates derived from alkyl- and sulphinylglucosinolates and indole-3-carbinol derived from the indole glucosinolates. Evidence from animal-model experiments suggests that isothiocyanates can protect against chemically-induced cancers. Zhang \& Talalay (1994) have reviewed the literature showing that aromatic isothiocyanates such as the benzyl and phenylethyl derivatives can protect experimental animals against chemically-induced cancers of the mammary glands, lung, forestomach and oesophagus. Some experiments have shown that feeding large single doses of intact glucosinolates, such as indolylmethyl glucosinolate or benzyl glucosinolate, can have tumour-blocking effects on 9,10-dimethyl-1,2-benzanthraceneinduced mammary tumours in rats. Zhang \& Talalay (1994) discuss the problems in interpretation of such experiments and the extent to which the effects resulting from feeding glucosinolates can be attributed to the glucosinolates themselves or their breakdown products is unclear. The products of indolylglucosinolate breakdown, indole-3-carbinol, 3-indole nitrile and the dimeric compound 3,3'-diindolylmethane have also been shown to inhibit chemically-induced cancer formation in experimental animals (Bradfield \& Bjeldanes, 1987). Zhang et al. (1992) showed that the activity in extracts of broccoli in inducing the anti-cancer phase-II enzyme, quinone reductase ( $E C$ 1.6.99.2) in a cultured-cell assay system could be largely attributed to the isothiocyanate, sulphoraphane (methylsulphinylbutyl-isothiocyanate). Sulphoraphane fed to rats blocked the formation of mammary tumours following treatment with 9,10-dimethyl-1,2benzanthracene (Zhang et al. 1994). At $75 \mathrm{mg} / \mathrm{d}$ sulphoraphane halved the number of rats in the trial with tumours and decreased the overall incidence of tumour formation by over $75 \%$. Zhang \& Talalay (1994) proposed that the anti-cancer properties of isothiocyanates are mediated by two related mechanisms. They suppress activation of carcinogens by cytochrome $\mathrm{P} 450$ by both down-regulating levels of this enzyme and by 
direct enzyme-inactivation, and they induce phase-II enzymes such as glutathione S-transferase and quinone reductase which detoxify xenobiotics and inhibit their ability to bind to DNA. Musk et al. (1995) have shown that benzyl isothiocyanate can cause chromosome abberations in cultured Chinese hamster cells. In Ames tests each of the seven isothiocyanates tested showed potential mutagenicity; the related compounds, the thiocyanates, were shown to be non-mutagenic. However, diets rich in Brassica vegetables are correlated with reduced incidence of many cancers (Graham, 1983) and it is unlikely that this potential mutagenicity is important in the dietary situation. Indeed, in experiments in which human subjects were fed on either a diet free of cruciferous vegetables (control group) or one containing $300 \mathrm{~g}$ Brussels sprouts/d, the group receiving the Brassica vegetables had significantly lower levels of DNA damage, measured by excretion of DNA metabolites, than the control group (Verhagen et al. 1995).

\section{Sulphur compounds from Allium vegetables}

Allium vegetables (onions, garlic, chives (Allium schoenoprasum), leek (Allium porrum)) contain a range of $\mathrm{S}$ compounds which are derivatives of L-cysteine sulphoxide (CSO) and a potential source of protective factors in the diet against degenerative diseases. In garlic the principal endogenous compound is 2-propenyl-CSO while in onions it is 1-propenyl-CSO. Both vegetables contain minor amounts of both methyland propyl-CSO. Table 3 shows that onion contains about $4.5 \mathrm{mg}$ total $\mathrm{CSO} / \mathrm{g}$ fresh weight of which approximately $80 \%$ is present as the 1-propenyl derivative. Rather higher levels (up to $7.9 \mathrm{mg} / \mathrm{g}$ ) are found in garlic, nearly all of which is the 2-propenyl compound. Chive contains much lower levels of CSO derivatives with methyl-CSO as the main constituent. CSO derivatives are localized in the cytoplasm of onion cells and are held separate from the hydrolytic enzyme, alliinase (EC 4.4.1.4), present in the cellular vacuole (Lancaster \& Collin, 1981). Alliinase is a well-characterized plant glycoprotein which requires pyridoxyl phosphate as a cofactor. It has been cloned recently from several Allium vegetables (Van Damme et al. 1992; Rabinokov et al. 1994). Cellular disruption during preparation, processing or chewing allows access of the alliinase to the CSO derivatives which are degraded to yield alk(en)ylthiosulphenic acids with the release of pyruvate and $\mathrm{NH}_{3}$. Thiosulphenates are unstable and are converted initially into the corresponding thiosulphinates. In garlic, the major initial product is the diallyl thiosulphinate, allicin, and this breaks down further to produce a range of S-containing products such as dialk(en)yl mono-, di- and tri-sulphates, thiols and a host of other compounds, both $\mathrm{S}$ compounds such as ajoene and non-S compounds including aldehydes. The chemistry of CSO breakdown is very complex and has been extensively reviewed recently by Block (1992). In onions, the situation is generally similar except that the initial thiosulphenic acid is converted to some extent to the lachrymatory compound, thiopropanal S-oxide, and loss of S occurs more frequently producing a range of aldehydic compounds. The final mixture of volatile products is determined by the nature of the initial CSO substrate, temperature, $\mathrm{pH}$ and is a feature of the Allium vegetable in question giving it its characteristic flavour and odour.

Onions and garlic have long been known to produce pharmacologically-active constituents. Trials in the 1980 s in China suggested that a high intake of Allium vegetables was correlated with significantly reduced risk of gastric cancer. Those with the highest quartile of intake had only a $40 \%$ risk of stomach cancer compared with the 
Table 3. Levels of cysteine sulphoxide derivatives found in Allium vegetables ( $m g / k g$ fresh weight) (Data from Edwards et al. 1994)

\begin{tabular}{lccc}
\hline \hline & $\begin{array}{c}\text { Onion } \\
\text { (Allium cepa) }\end{array}$ & $\begin{array}{c}\text { Garlic } \\
\text { (Allium sativum) }\end{array}$ & $\begin{array}{c}\text { Chives } \\
\text { (Allium schoenoprasum) }\end{array}$ \\
\hline Methyl cysteine sulphoxide & 7 & $\operatorname{tr}$ & 8 \\
1-Propenyl cysteine sulphoxide & $35 \cdot 7$ & $\operatorname{tr}$ & 4 \\
2-Propenyl cysteine sulphoxide & $\operatorname{tr}$ & 79 & - \\
Propyl cysteine sulphoxide & $2 \cdot 8$ & $\operatorname{tr}$ & $12 \cdot 2$ \\
Total & $45 \cdot 5$ & 79 & \\
\hline \hline
\end{tabular}

tr, Small amount detected but not quantified.

lowest quartile (You et al. 1989). Belman (1983) has shown that garlic and onion oils inhibit the formation of phorbol ester-induced cancers in mice in a dose-dependent manner; onion being rather more effective. Individual CSO degradation products such as diallyl disulphide produced in garlic inhibit oesophageal cancer formation in $\mathrm{N}$ nitrosomethylbenzylamine-treated rats (Wargovich et al. 1988), while the related compound, diallyl sulphide, inhibits dimethylhydrazine-induced colon cancer in mice (Wargovich, 1987). In a study of benzopyrene-induced neoplasia of the forestomach and lung in female mice, Sparins et al. (1988) tested eight sulphides formed in onion and garlic, applied 96 or $48 \mathrm{~h}$ after the carcinogen. Compounds such as diallyl mono-, di-, and tri-sulphide were all active, while suphides which have saturated substituents were inactive. A number of alkenyl suphides have been shown to be active in inducing the phase-II enzyme, GST, in human cells in culture. Among the diallyl derivatives the monosulphide showed only low activity, while both the di- and tri-sulphide showed high activity with concentrations below the $1 \mu \mathrm{M}$ level giving half-maximal activity (M. J. C. Rhodes, G. W. Williams, J. Bacon and S. DuPont, unpublished results).

In folk medicine garlic extracts have been used for the treatment of heart disease. Garlic extracts have been shown to inhibit blood platelet aggregation (Boullin, 1981). In a recent study of the active principles involved Lawson et al. (1992) found that diallyl disulphide and allicin were the most active garlic constituents in inhibiting platelet aggregation. There is little information on the bioavailability of CSO degradation products. This is confounded by the complexity of the chemistry of the further breakdown of the products of the alliinase reaction. Lawson et al. (1992) were unable to detect allicin or any other transformation products in either blood or urine samples 1,2 , 4 and $24 \mathrm{~h}$ after human volunteers had consumed $25 \mathrm{~g}$ chopped garlic in a single dose. Allicin is known to react with free cysteine or cysteine peptides and Lawson et al. (1992) speculate that allicin may react with cysteine in the intestinal lumen to form S-allyl mercaptocysteine, which may be the form absorbed into the bloodstream. One recent study of the pharmacokinetic behaviour of the garlic constituent, S-allylcysteine, has shown that after oral administration to rats, mice or dogs it is rapidly and easily absorbed in the gastrointestinal tract and either excreted unchanged or as its $\mathrm{N}$-acetyl derivative (Nagae et al. 1994). However, for most of the potential pharmacologically-active constituents very little is known of their uptake and metabolism and the concentrations of these compounds to which gut and liver cells in humans are exposed. 


\section{CONCLUSION}

The extent to which it is possible to explain the beneficial effects of diets rich in fruit and vegetables in terms of putative protective factors, such as flavonoids, isothiocyanates or allyl disulphides discussed in the present paper, remains uncertain. They have clearly demonstrable benefits in animal model experiments. Yet, so little is known of their bioavailability in man that it is difficult to judge their importance. For compounds such as the volatile isothiocyanates and sulphides of Brassica and Allium vegetables it is difficult to measure the actual levels of these compounds arising in the diet because of the complexities of their formation. Even with the flavonoids, where the situation would appear to be much simpler, the level of dietary intake is controversial.

For many of the compounds discussed in the present paper, there is evidence that they can have both beneficial and harmful nutritional effects. Yet, the evidence from epidemiological studies suggests that diets rich in fruit and vegetables have a net beneficial effect to health. Assuming that the beneficial role of the putative protective factors is established, it is likely that there is a concentration window of these compounds which is beneficial to health and above which deleterious effects may come into play. Defining this window would be an important future research task, to gauge the benefits and limitations of increased consumption of plant foods containing these compounds.

\section{REFERENCES}

Aldercreutz, H., Markkanen, H. \& Watanabe, S. (1993). Plasma concentrations of phyto-oestrogens in Japanese men. Lancet 342, 1209-1210.

Azen, E. A., Latrellie, P. \& Niece, R. L. (1993). PRB1 gene variants coding for length and null polymorphisms among human salivary Ps, PmF, PmS and Pe proline-rich proteins. American Journal of Human Genetics 53, 264-278.

Belman, S. (1983). Onion and garlic oils inhibit tumor promotion. Carcinogenesis 4, 1063-1065.

Block, E. (1992). The organosulfur chemistry of the Genus Allium - Implications for the organic chemistry of sulfur. Angewandte Chemie - International Edition in English 31, 1135-1178.

Block, G., Patterson, B. \& Subar, A. (1992). Fruit, vegetables and cancer prevention. A review of the epidemiological evidence. Nutrition and Cancer 18, 1-29.

Boullin, D. J. (1981). Garlic as a platelet inhibitor. Lancet i, 776-777.

Boutin, J. A., Meunier, F., Lambert, P.-H., Hennig, P., Bertin, D., Serkiz, B. \& Volland, J.-P. (1993). In vivo and in vitro glucuronidation of the flavonoid diosmetin in rats. Drug Metabolism and Deposition 21, 1157-1166.

Bradfield, C. A. \& Bjeldanes, L. F. (1987). Structure-activity relationships of dietary indoles: A proposed mechanism of action as modifiers of xenobiotic metabolism. Journal of Toxicology and Environmental Health 21, 311-323.

Cassidy, A., Bingham, S. \& Setchell, K. D. R. (1994). Biological effects of a diet of soy protein rich in isoflavones on the menstrual cycle of premenopausal women. American Journal of Clinical Nutrition 60 , 333-340.

Das, N. P. \& Ratty, A. K. (1986). Effects of flavonoids on induced non-enzymic lipid peroxidation. In Plant Flavonoids in Biology and Medicine: Biochemical Pharmacological and Structure Activity Relationships, pp. 243-247 [V. Cody, E. Middleton and J. B. Harborne, editors]. New York: Alan R. Liss.

Edwards, S. J., Musker, D., Collin, H. A. \& Britton, G. (1994). The analysis of S-alk(en)yl-L-cysteine sulphoxides (flavour precursors) from species of Allium by high performance liquid chromatography. Phytochemical Analysis 5, 4-9.

Graham, S. (1983). Results of case-control studies of diet and cancer in Buffalo, New York. Cancer Research 43, 2409s-2413s.

Hackett, A. M. (1986). The metabolism of flavonoid compounds in mammals. In Plant Flavonoids in Biology and Medicine: Biochemical Pharmacological and Structure Activity Relationships, pp. 17-194 [V. Cody, E. Middeleton and J. B. Harborne, editors]. New York: Alan R. Liss. 
Hagerman, A. E. \& Butler, L. G. (1981). The specificity of proanthocyanin-protein interactions. Journal of Biological Chemistry 256, 4494-4497.

Hertog, M., Feskens, E. J. M., Hollman, P. C. H., Katan, M. B. \& Kromhout, D. (1993a). Dietary antioxidant flavonoids and risk of coronary heart disease: The Zutphen Elderly Study. Lancet 342, 1007-1011.

Hertog, M., Hollman, P. C. H., Katan, M. B. \& Kromhout, D. (1993b). Intake of potentially anticarcinogenic flavonoids and the determinants in adults in the Netherlands. Nutrition and Cancer 20, 21-29.

Johnson, I. T., Williamson, G. \& Musk, S. R. R. (1994). Anticarcinogenic factors in plant foods; a new class of nutrients? Nutrition Research Reviews 7, 175-204.

Kühnau, J. (1973). The flavonoids: a class of semi-essential food components: their role in human nutrition. World Review of Nutrition and Dietetics 24, 117-191.

Lancaster, J. E. \& Collin, H. A. (1981). Presence of alliinase in isolated vacuoles and of alkyl cysteine sulphoxides in the cytoplasm of bulbs of onion (Allium cepa). Plant Science Letters 22, 169-176.

Lawson, L. D., Ransom, D. K. \& Hughes, B. G. (1992). Inhibition of whole blood platelet-aggregation by compounds in garlic clove extracts and commercial garlic products. Thrombosis Research 65, 141-156.

Leibovitz, B. E. \& Mueller, J. A. (1993). Bioflavonoids and polyphenols: medical applications. Journal of Optimal Nutrition 2, 17-35.

Murray, N. J. \& Williamson, M. P. (1994). Conformational study of a salivary proline-rich protein repeat sequence. European Journal of Biochemistry 219, 915-921.

Musk, S. R. R., Astley, S. B., Edwards, S. M., Stephenson, P., Hubert, R. B. \& Johnson, I. T. (1995), Cytotoxic and clastogenic effects of benzyl isothiocyanate towards cultured mammalian cells. Food and Chemical Toxicology 33, 31-37.

Nagae, S., Ushijima, S., Imai, J., Kasuga, S., Matsuura, H., Itakura, Y. \& Higashi, Y. (1994). Pharmacokinetics of the garlic compound S-allylcysteine. Planta Medica 60, 214-217.

Pierpoint, W. S. (1990). Flavonoids in human food and animal feedstuffs. In Flavonoids in Biology and Medicine, vol. 3, Current Issues in Flavonoid Research, pp. 497-514 [N. P. Das, editor]. Singapore: National University of Singapore.

Rabinokov, A., Zhu, X.-Z., Graf, G., Galili, G. \& Mirelman, D. (1994). Alliin lyase (Alliinase) from garlic: Biochemical characterisation and cDNA cloning. Applied Biochemistry and Biotechnology 48, 149-171.

Rhodes, M. J. C. (1994). Physiological roles for secondary metabolites in plants; some progress, many outstanding problems. Plant Molecular Biology 24, 1-20.

Rice-Evans, C. A., Miller, N. J., Bolwell, P. G., Bramley, P. M. \& Pridham, J. B. (1995). The relative antioxidant activities of plant-derived polyphenolic flavonoids. Free Radical Research 22, 375-383.

Sanejima, K., Kanazawa, K., Ashida, H. \& Danno, G. (1995). Luteolin: a strong antimutagen against dietary carcinogen, Trp-p-2 in peppermint, sage and thyme. Journal of Agricultural and Food Chemistry 43, $410-414$

Sparins, V. L., Barany, G. \& Wattenberg, L. W. (1988). Effects of organosulfur compounds from garlic and onions on benzo( $\alpha$ )yrene-induced neoplasia and glutathione-S-transferase activity in the mouse. Carcinogenesis 9, 131-134.

Van Damme, E. J. M., Smeets, K., Torrekens, S., Van Leuven, F. \& Peumans, W. J. (1992). Isolation and characterisation of alliinase cDNA clones from garlic (Allium sativum L.) and related species. European Journal of Biochemistry 209, 751-757.

Verhagen, H., Poulsen, H. E., Loft, S., van Poppel, G., Willems, M. I. \& van Bladeren, P. J. (1995). Reduction of oxidative DNA-damage in humans by Brussels sprouts. Carcinogenesis 16, 969-970.

Wargovich, M. J. (1987). Diallyl sulfide, a flavour component of garlic (Allium sativum) inhibits dimethylhydrazine-induced colon cancer. Carcinogenesis 8, 487-489.

Wargovich, M. J., Woods, C., Eng, V. W. S., Stephens, I. C. \& Gray, K. (1988). Chemoprotection of Nnitrosomethylbenzylamine-induced esophageal cancer in rats by the naturally-occurring thioether, diallyl sulfide. Cancer Research 48, 6872-6875.

Wattenburg, L. W. \& Loub, W. D. (1978). Inhibition of polycyclic aromatic hydrocarbon-induced neoplasia by naturally occurring indoles. Cancer Research 38, 1410-1413.

Wilkinson, A. P., Rhodes, M. J. C. \& Fenwick, R. G. (1984). Myrosinase activity in cruciferous vegetables. Journal of the Science of Food and Agriculture 35, 543-552.

Xue, J., Lenman, M., Falk, A. \& Rask, L. (1992). The glucosinolate-degrading enzyme myrosinase in the Brassicacae is encoded by a gene family. Plant Molecular Biology 18, 387-398.

You, W.C., Blot, W. J., Chang, Y.-S., Ershow, A., Yang, Z. T., An, Q., Henderson, B. E., Fraumeni, J. F. Jr \& Wang, T.-G. (1989). Allium vegetables and reduced risk of stomach cancer. Journal of the National Cancer Institute 81, 162-164. 
Zhang, Y., Kensler, T. W., Cho, C.-G., Posner, G. H. \& Talalay, P. (1994). Anticarcinogenic activities of sulforaphane and structurally related norbornyl isothiocyanates. Proceedings of the National Academy of Sciences, USA 91, 3147-3150.

Zhang, Y. \& Talalay, P. (1994). Anticarcinogenic activities of organic isothiocyanates: chemistry and mechanisms. Cancer Research 54, Suppl., 1976s-1981s.

Zhang, Y., Talalay, P., Cho, C.-G. \& Posner, G. H. (1992). A major inducer of anticarcinogenic protective enzymes from broccoli: Isolation and elucidation of structure. Proceedings of the National Academy of Sciences, USA 89, 2399-2403. 